\title{
ІНФОРМАЦІЙНА ТЕХНОЛОГІЯ ОЦІНЮВАННЯ ЗМІН ПЕРІОДІВ ЕПЛЕПТИЧНОГО НАПАДУ
}

\author{
Білошицька О.К., ст. викладач \\ o.biloshytska@kpi.ua \\ Кафедра біомедичної інженерії \\ Національний технічний університет України \\ «Київський політехнічний інститут імені Ігоря Сікорського» \\ м. Київ, Україна
}

Реферат - Запропонована інформаційна технологія прогнозування настання епілептичного нападу на основі сигналу ЕЕГ, яка використовує розроблений програмний комплекс розрахунку показників складності та варіабельності поведінки сигналу ЕЕГ, а також побудовані на основі цчих показників індивідуалізовані прогностичні моделі з урахуванням локалізації патологічних зон, уможливлює ідентифікувати періоди функиіонування головного мозку у хворих на епілепсію.

Ключевые слова - інформаційна технологія, система підтримки прийняття рімень, бізнес-процеси, ЕЕГ, епілепсія.

\section{I. ВСТУП}

Розповсюдженість епілепсії в розвинутих країнах складає 5-10 випадків на 1000 населення. Згідно 3 результатами популяційних досліджень, проведених в розвинутих країнах, частота розвитку епілепсії коливається в межах від 0,28 до 0,53 випадків на 1000 населення. В країнах СНД розповсюдженість епілепсії коливається від 0,96 до 10 випадків на 1000 населення. В Свропі на епілепсію страждає 6 млн. осіб, 3 них $40 \%$ не отримує належного лікування $[1,2]$.

Використання ЕЕГ у епілептології має на меті: підтвердження наявності аномальної для здорового мозку електричної епілептиформної активності; визначення типу нападів та форми епілептичного захворювання та локалізації фокуса активності нападу у об'ємі мозку та його проекції на поверхню голови; моніторинг перебігу хвороби; допомогу у корегуванні лікування; прогноз розвитку хвороби.

Зменшення часу для оброблення, підвищення ефективності роботи лікаря та зменшення кількості помилок під час пошуку епілептиформних комплексів у ЕЕГ можна досягти застосуванням автоматизованих методів оброблення та аналізування сигналу. Тому досить актуальним є завдання побудови алгоритмів, які дають змогу повністю автоматизувати процедуру аналізу електроенцефалограм нелінійними методами [3-7].

Однією 3 технічних проблем в розвитку цього напряму є ресурсомісткість обчислень, а також необхідність участі оператора в їх процесі. Тому досить актуальним є завдання побудови алгоритмів, які дають змогу повністю автоматизувати процедуру аналізу електроенцефалограм нелінійними методами [8].

\section{II. МЕТА ДОСЛІДЖЕННЯ}

Проблема діагностики та виявлення моменту, який передує епілептичному нападу, або інших періодів функціонування головного мозку у хворих на епілепсію $\epsilon$ актуальною в науково-практичній площині. Великий інтерес становить створення моделей прогнозування настання епілептичного нападу для конкретного пацієнта, які базуються на спільному використанні показників варіабельності та складності.

У наявних системах автоматизованого виділення патернів епілептиформної активності використовуються методики, які наразі не можуть допомогти лікарю у знаходженні епілептиформних комплексів ЕЕГ. Загалом відсутні спроби адаптації процедури 
оброблення сигналу ЕЕГ для локалізації епілептиформних комплексів конкретного пацієнта та для забезпечення поточних потреб лікаря.

Для аналізу стану діяльності головного мозку розроблено системи підтримки прийняття рішень на основі методів машинного навчання за технологією нейронних мереж. Однак ці системи не враховують види прийняття рішень, які може використовувати лікар для прогнозування настання певної патологічної ділянки за ЕЕГ, щоб вчасно запобігти виникненню епілептичного нападу.

Отже, частота розповсюдженості епілепсії, необхідність точної діагностики та оцінювання ефективності лікувальнодіагностичного процесу зумовлюють актуальність розроблення інформаційного забезпечення для реалізації процесу прийняття рішень за сигналами ЕЕГ.

\section{III. МОДЕЛЮВАННЯ БІЗНЕС- ПРОЦЕСІВ ДІАГНОСТИКИ ЕПІЛЕПСІЇ}

Для чіткішого розуміння процесу діагностики епілепсії на основі ЕЕГ було проведено моделювання бізнес-процесів [911] за допомогою контекстної діаграми в нотації IDEF0 (рис. 1). Базуючись на уніфікованих клінічних протоколах медичної допомоги, законах України та медико-статистичних формах (як облікових, так і звітних), лікар 3 функціональної діагностики за зареєстрованою ЕЕГ може зробити висновок щодо діяльності мозку у хворих на епілепсію.

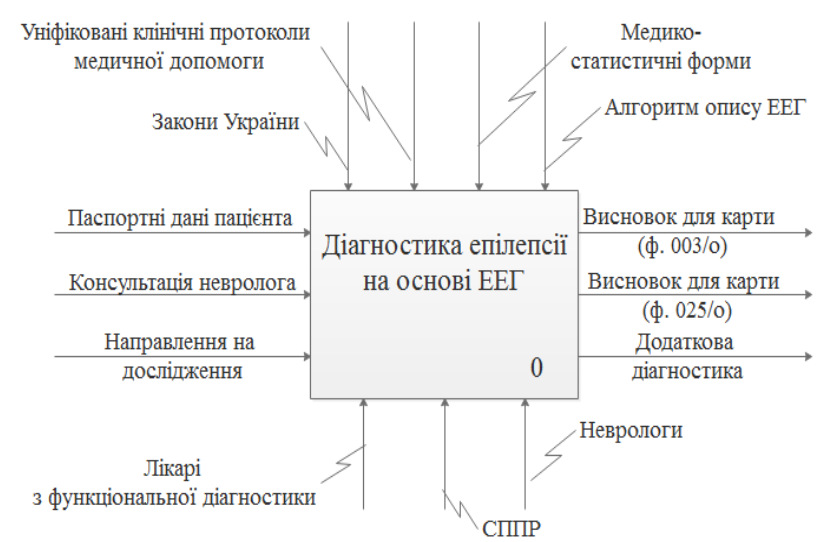

Рис. 1. Контекстна діаграма «Діагностика епілепсії на основі ЕЕГ»
Діаграма першого рівня декомпозиції системи підтримки прийняття рішень (СППР) представлено на рис. 2. Основні описуються функції за допомогою декомпозиції процесу «Діагностика епілепсії на основі ЕЕГ».

На початковому етапі відбувається внесення паспортних даних пацієнта до бази даних, попередній діагноз з направлення на дослідження, відбувається накладання електродів на голову досліджуваної особи, реєстрація ЕЕГ та проведення функціональних проб.

Після початку реєстрації ЕЕГ за допомогою програмного забезпечення, що поставляється разом 3 комп'ютерним електроенцефалографом, графіка ЕЕГ перетворюється у масив даних по кожному відведенню ЕЕГ та передається до програмного модуля. Також на цьому етапі відбувається відбір інформативних каналів (де наявні відхилення від нормального ритму ЕЕГ). За допомогою програмного модуля здійснюється розрахунок показників складності та відбувається побудова прогностичних моделей.

Далі відбувається передача розрахованих показників складності та побудованих прогностичних моделей до бази даних та накопичуються у базі знань. За допомогою інтерфейсу користувача відбувається виведення результатів про поточну ділянку за ЕЕГ та повідомлення про вірогідність настання наступного періоду за ЕЕГ.

На останньому етапі відповідно до облікових медичних форм, законів України та уніфікованих клінічних протоколів медичної допомоги відбувається підготовка висновків для медичної карти стаціонарного хворого (ф. 003/o) та медичної карти амбулаторного хворого (ф. 025/о).

При створенні СППР було використано мову моделювання UML, яка дозволяє не тільки представити процес зміни iii станів, але i деталізувати особливості алгоритмічної i логічної реалізації виконуваних системою операцій. Для моделювання процесу виконання операцій в мові UML використовуються так звані діаграми діяльності. 


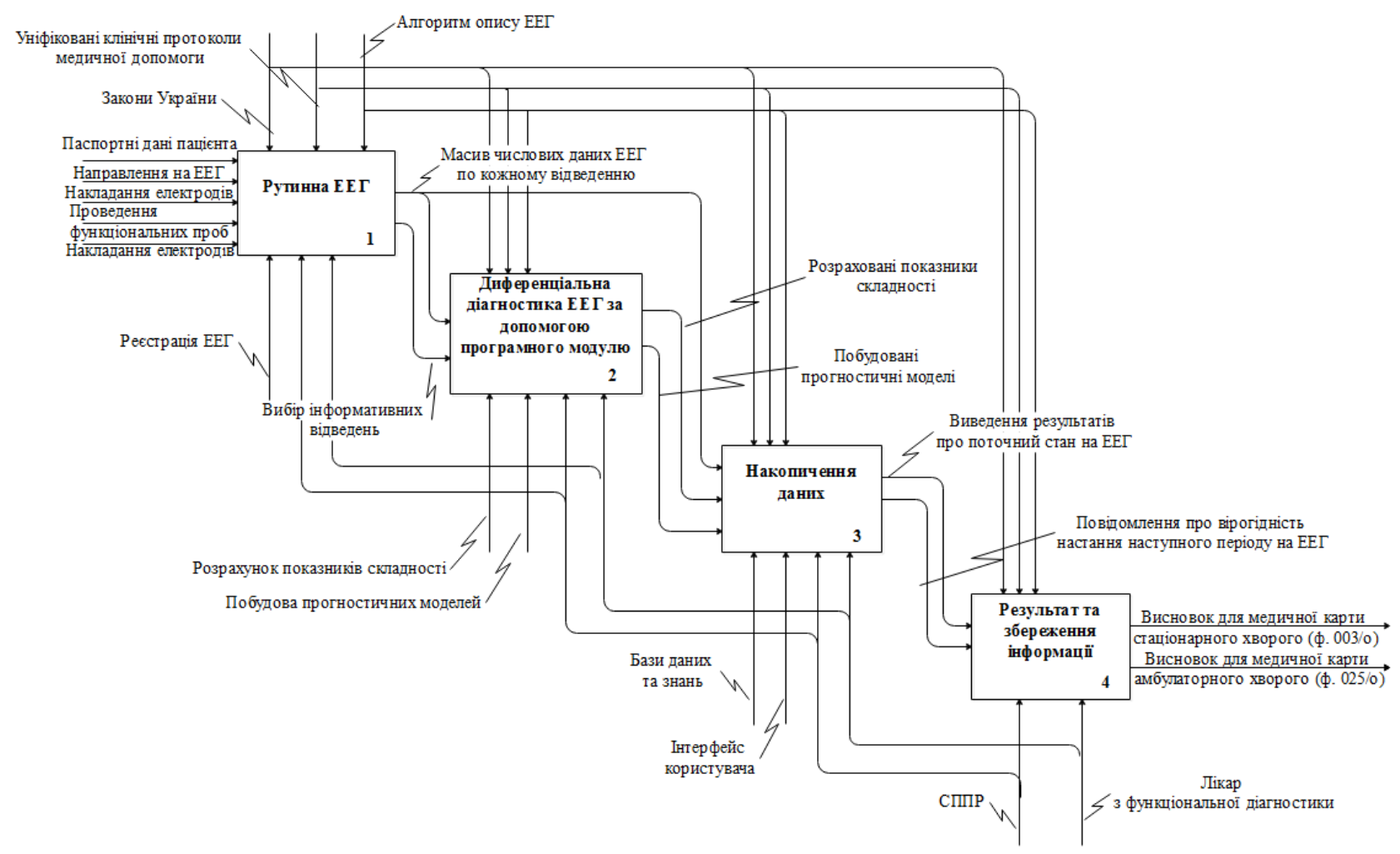

Рис. 2. Визначення періоду перебігу епілепсії у хворих за ЕЕГ (декомпозиція І рівня)

Система автоматичного виявлення нападів та діагностики епілепсії складається 3 офлайн і онлайн-системи. Автономна система складається з етапів проектування, необхідних для створення та тестування структури алгоритму СППР. Надалі цей алгоритм лікарі 3 функціональної діагностики використовують в онлайн-системі у якості СППР.

Для дослідження ЕЕГ у офлайн системі лікар має можливість завантажити сигнал 3 попередньо збережених періодів ЕЕГ, або самостійно вибрати ділянку сигналу для аналізу. В режимі реального часу відбувається послідовний аналіз всієї ЕЕГ [12].

Підпрограма вибору ділянки сигналу (періоду) дозволяє аналізувати сигнали ЕЕГ, отримані 3 електроенцефалографів різних виробників, а також використовувати відкриті бази даних для проведення досліджень.

Створення програмного забезпечення системи, а саме модулю накопичення даних, дає змогу автоматизувати збір та збереження даних вимірювань, які надходять від апаратного та програмного модулів. Всі зареєстровані ЕЕГ надходять до комп'ютера користувача (дослідника) за застосування відповідного програмного забезпечення електроенцефалографа, в базі даних фіксується персональна інформація про пацієнта 3 додержанням правил, які висуваються комплексною системою захисту інформації: цілісність, доступність та конфіденційність.

Розроблене програмне забезпечення містить в собі таку інформацію [13]:

- дані про пацієнта: ПІБ, стать, дата народження, діагноз направлення;

- історію зареєстрованих раніше ЕЕГ пацієнтів;

- значення розрахованих показників складності: показник Херста, значення фрактальної розмірності, показник алгоритмічної складності за Колмогоровим, показник складності методом LZW, значення логістичного відображення;

- прогностичні моделі для кожної 3 зон головного мозку: на основі покрокової логістичної регресії та покрокового дискримінантного аналізу.

Для правильного функціонування системи, яка реалізує розроблену інформаційну технологію, потрібно забезпечити можливості модифікації окремих елементів програмного модулю без внесення 
змін до інших компонентів системи.

До модуля накопичення даних входить два основних компоненти: інтерфейс користувача, що розроблений за допомогою мови програмування Python 2.7 та інтегрованого середовища розробки було використано PyCharm Community Edition, та бази даних системи EEGdia.

На робочому місці лікар/дослідник використовує графічний інтерфейс програмного забезпечення електроенцефалографа для візуалізації записів сигналів ЕЕГ та графічний інтерфейс розробленого програмного забезпечення для відображення результатів зміни динаміки розрахованих показників i отриманих прогностичних моделей. Зв'язок 3 розробленою базою даних EEGdia здійснюється через СКБД. В БД також зберігаються всі дані досліджень. На основі зареєстрованих раніше ЕЕГ можна проводити додаткові дослідження з даними, які необхідно відбирати, сортувати та класифікувати для подальшого використання в статистичній обробці.

Для уникнення можливих складностей під час аналізу ЕЕГ та точної класифікації ділянки за ЕЕГ всі методи, що представлені у попередніх розділах, реалізовані у вигляді окремих систем у програмному модулі. Розроблене програмне забезпечення для ідентифікації певної ділянки за ЕЕГ включає основні дві системи: систему розрахунку показників варіабельності та складності сигналу ЕЕГ та систему визначення стану ділянки сигналу ЕЕГ на основі прогностичних моделей.

Реєстрація ЕЕГ відбувається в реальному часі за допомогою стандартного програмного забезпечення, яке постачається разом 3 електроенцефалографом. При цьому обов'язково вводяться персональні дані пацієнта для його подальшої ідентифікації та порівнянні отриманих результатів 3 попередніми. Реєстрація ЕЕГ відбувається за стандартною методикою - міжнародною системою відведень «10-20» та проведенням функціональних проб: очі відкриті, очі закриті, фотостимуляція на різних частотах (від 2 Гц до 18 Гц) та гіпервентиляція (протягом трьох хвилин). Оцифровані дані ЕЕГ нормуються та зберігаються в базі даних.
За розробленою технологією підтримка прийняття рішень під час діагностичного процесу визначення періодів епілептичного нападу за ЕЕГ здійснюється у три етапи [13].

На першому етапі відбувається передача зареєстрованої ЕЕГ за допомогою відповідного програмного забезпечення комп'ютерного електроенцефалографа до системи. Спочатку реєструється фонова ЕЕГ у спокійному стані. Досліджується функціонування головного мозку у спокійному стані за умов впливу зовнішніх та внутрішніх чинників, у подальшому здійснюється реєстрація ЕЕГ 3 функціональними пробами та проводиться їхнє порівняння. Для кожного періоду перебігу епілепсії здійснюється розрахунок таких показників складності, як показник Херста, фрактальна розмірність, алгоритмічна складність сигналу та логістичне відображення.

На другому етапі із застосуванням розрахованих показників варіабельності та складності здійснюється побудова прогностичних моделей. Використовуються дані інформативних каналів ЕЕГ, які відповідають виявленим зонам ураження головного мозку.

Спочатку ідентифікується період перебігу епілепсії за допомогою покрокового дискримінантного аналізу показників ЕЕГ зі стратегією «один проти всіх». Потім перевіряється зазначена ділянка на визначення періоду методом покрокової логістичної регресії також зі стратегією «один проти всіх». У разі, коли отримані значення $є$ досить близькими, використовується стратегія «один до одного» у покроковій логістичній регресії для точного визначення періоду. Перевірка адекватності розроблених моделей полягає в порівнянні 3 раніше отриманими результатами, що зберігаються в базі знань інформаційної системи.

Отримані результати прогнозу доповнюються даними інших клінічних обстежень, які $є$ в наявності у лікаря. На основі цих даних генерується рішення щодо поточного стану хворого.

На третьому етапі формуються діагностичні показники із зазначенням ваги кожного показника складності в інформативних відведеннях патологічних зон. 
Зроблені висновки щодо поточного стану пацієнта формуються у вигляді повідомлення на екрані у лікаря та виводиться прогноз щодо ймовірності настання наступного епілептичного нападу.

\section{IV. ОБГОВОРЕННЯ РЕЗУЛЬТАТІВ}

\section{Розроблена СППР підвищує} інформаційне забезпечення лікаря та сприяє об'єктивізації процесу постановки діагнозу за рахунок автоматичної класифікації елементів ЕЕГ відповідно до розрахованих значень функцій прогностичних моделей, а також класифікації за ступіню патологічної значимості. Подібна можливість відсутня в існуючих програмах математичної обробки ЕЕГ, оскільки вони реалізують лише спектральні та кореляційні види аналізів, в результаті чого втрачається інформація про різнорідні елементи ЕЕГ через зважене усереднення всіх відліків сигналу. Маючи додаткову інформацію про класи періодів за ЕЕГ, лікар прийме найбільш достовірне рішення про ЕЕГ в цілому.

$\begin{array}{ccr}\text { Для } & \text { перевірки } & \text { ефективності } \\ \text { розробленої } & \text { системи було } & \text { проведено } \\ \text { порівняльне } & \text { оцінювання } & \text { результатів }\end{array}$
класифікації ділянок ЕЕГ, які здійснювали лікарі $з$ функціональної діагностики під час рутинної ЕЕГ (візуальний аналіз) та за допомогою розробленої СППР.

\section{використання}

розробленої

інформаційної технології оброблення ЕЕГ за рахунок надання лікарю ймовірності настання певного періоду за ЕЕГ дає змогу зорієнтувати його у прийнятті рішення, підвищити точність класифікації періодів умовної норми, перед нападом, нападу та після нападу в середньому на $5,5 \%, 4,4 \%, 9,9 \%$ та $6,6 \%$ відповідно у дітей, а у дорослих на 9,2\%, 7,4\%, 8,5\% та 6,9\% відповідно.

Також було порівняно час (у секундах), який витрачався на визначення періоду за ЕЕГ без використання СППР та 3 нею. Отримані результати занесено до таблиці 5.3.

За рахунок зменшення часу визначення лікарем періоду за ЕЕГ розроблена інформаційна технологія дозволяе зорієнтувати лікаря у прийнятті рішення, швидше класифікувати періоди умовної норми, перед нападом, напад та після нападу в середньому на $19 \%, 15,5 \%, 15,4 \%, 16,9 \%$ відповідно у дітей, а у дорослих на 23,9\%, 18\%, 23,3\%, 17,8\% відповідно.

Насамперед, розроблена інформаційна технологія $\epsilon$ корисною у діагностичних відділеннях закладів охорони здоров'я, де проводиться реєстрація та аналіз електроенцефалографії, a також для психоневрологічних стаціонарів.

\section{ПЕРЕЛІК ПОСИЛАНЬ}

[1] Уніфікований клінічний протокол первинної, екстреної, вторинної (спеціалізованої) та третинної (високоспеціалізованої) медичної допомоги епілепсії у дорослих. Київ, 2014.2 URL: http://mtd.dec.gov.ua/images/dodatki/2014_276_Epilepsii/2014_2 76 YKPMD epilepsiya dorosli.pdf.

[2] Уніфікований клінічний протокол первинної, екстреної, вторинної (спеціалізованої) та третинної (високоспеціалізованої) медичної допомоги епілепсії у дітей Київ, 2014.2 URL: http://mtd.dec.gov.ua/images/dodatki/2014_276_Epilepsii/2014_2 76_YKPMD_epilepsiya_dity.pdf.

[3] Майоров О.Ю., Фенченко В.Н. Исследование биоэлектрической активности мозга с позиций многоразмерного линейного и нелинейного анализа ЭЭГ. Клин. информ. и телемед. Харьков, 2008. Т.4, вып. 5. С. 12-20.

[4] Панічев О. Ю. Методи аналізу ЕЕГ для прогнозування епілептичних нападів. Биомедицинские приборы и системы. Киев, 2015. №3. С. 68- 77.

[5] Аристов А. В. Фрактальный анализ электрической активности головного мозга при генерализованной эпилепсии: дис. канд. биол. наук: 03.03.01 / Московский государственный университет им. М.В. Ломоносова. Москва, 2010. $156 \mathrm{c}$.

[6] Білошицька О. К. Аналіз та оцінка нелінійних характеристик епілептичних ЕЕГ-сигналів. Вчені записки Таврійського національного університету імені B.I. Вернадського. Серія: Технічні науки. 2018 . №29 (68). Ч. 1. С. 80-85.

[7] Білошицька О. К., Клименко Т. А. Дослідження показників епілептичних ЕЕГ-сигналів за допомогою методів нелінійної динаміки. Вісник НТУ «ХПІ». Серія: Механіко-технологічні системи та комплекси. 2017. №19 (1241). С. 30-34.

[8] Майоров О.Ю. Компьютерная ЭЭГ - прошлое, настоящее, будущее Клин. информ. и телемед. Харьков, 2004. Т.1, вып. 2. C. $165-173$.

[9] Висоцька О. В. Інформаційна технологія підтримки прийняття рішень при здійсненні діагностично-лікувальних процесів: дис. ... д-ра техн. наук / 05.13.09 / Міжн. наук.-навч. центр інформ. техн. та систем. Київ, 2015, 362 с.

[10] Репин В. В., Елиферов В. Г. Процессный подход к управлению. Моделирование бизнес-процесов. Москва, 2004. $398 \mathrm{c}$.

[11] Черемных С. В., Семенов И. О., Ручкин В. С. Структурный анализ систем: IDEF-технологии. Москва, 2003. $208 \mathrm{c}$.

[12] Білошицька О. К. Нелінійна динаміка як інструмент прогнозування патологічних змін на електроенцефалограмі. Вісник НТУ «ХПІ». Серія: Механіко-технологічні системи та комплекси. 2016. №50 (1222). С. 79-83.

[13] Білошицька О.К. Інформаційна технологія оцінювання перебігу епілепсії за показниками складності електроенцефалографії: дис. ... канд. техн. наук: 05.13.09 / Міжнародний науково-навчальний центр інформаційних технологій та систем НАН України та МОН України. Київ, 2019 p. 183 c. 


\title{
ИНФОРМАЦИОННАЯ ТЕХНОЛОГИЯ ОЦЕНИВАНИЯ ИЗМЕНЕНИЙ ПЕРИОДОВ ЭПИЛЕПТИЧЕСКОГО ПРИСТУПА
}

\author{
Белошицкая О.К., ст. преподавтель \\ o.biloshytska@kpi.ua \\ Кафедра биомедицинской инженерии \\ Национального технического университета Украины \\ Киевский политехнический институт имени Игоря Сикорского» \\ г. Киев, Украина
}

Реферат - Предложенная информаџионная технология прогнозирования наступления эпилептического приступа на основе сигнала ЭЭГ, которая использует разработанный программный комплекс расчета показателей сложности и вариабельности поведения сигнала ЭЭГ, а также построеннье на основе этих показателей индивидуализированные прогностические модели с учетом локализации патологических зон, способствует идентификащии периодов функционирования головного мозга у больных эпилепсией.

Ключевые слова - информационная технология, система поддержки принятия решений, бизнес-процессы, ЭЭГ, эпилепсия.

\section{INFORMATION TECHNOLOGY FOR ESTIMATING CHANGES IN SEIZURES}

Biloshytska O.K., Senior Lecturer

o.biloshytska@kpi.ua

Department of Biomedical Engineering

National Technical University of Ukraine "Igor Sikorsky Kyiv Polytechnic Institute",

Kiev, Ukraine

\begin{abstract}
According to the technology developed, decision support during the diagnostic process of determining periods of epileptic seizure by EEG is carried out in three stages: obtaining and processing of data, development of prognostic models and formation of diagnostic conclusions. The information technology of the prediction of the occurrence of epileptic seizure on the basis of an EEG signal which uses the developed software of complexity and variability indices calculation, and also built on the basis of these indices individualized prognostic models, with use of informative leads, enables to identify the periods of functioning of the brain in patients with epilepsy.
\end{abstract}

Keywords - information technology, pay-per-acceptance system, business process, EEG, epilepsy. 